$\begin{array}{r}\text { ANGIELS } \\ \text { NEW PERSPECTUE5 } \\ \hline\end{array}$

ANELOPHONE WORLD

\section{Angles}

New Perspectives on the Anglophone World

5 | 2017

The Cultures and Politics of Leisure

\title{
"Tote Clubs", Dog Tracks and Irish Sweepstake: Controversy and Compromise Over Popular Gambling in Interwar Britain
}

\section{Emmanuel Roudaut}

\author{
(2) OpenEdition \\ Journals \\ Electronic version \\ URL: https://journals.openedition.org/angles/1278 \\ DOI: $10.4000 /$ angles. 1278 \\ ISSN: 2274-2042 \\ Publisher \\ Société des Anglicistes de l'Enseignement Supérieur
}

\section{Electronic reference}

Emmanuel Roudaut, "'Tote Clubs", Dog Tracks and Irish Sweepstake: Controversy and Compromise Over Popular Gambling in Interwar Britain", Angles [Online], 5 | 2017, Online since 01 November 2017, connection on 08 June 2022. URL: http://journals.openedition.org/angles/1278; DOI: https://doi.org/ 10.4000 /angles. 1278

This text was automatically generated on 8 June 2022.

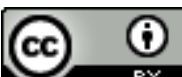

Angles est mise à disposition selon les termes de la Licence Creative Commons Attribution 4.0 International. 


\title{
"Tote Clubs", Dog Tracks and Irish Sweepstake: Controversy and Compromise Over Popular Gambling in Interwar Britain
}

\author{
Emmanuel Roudaut
}

In 1927, writing to his colleague at the Home Office, the Chancellor of the Exchequer described gambling as a "rather difficult, highly controversial and moderately important subject" (Miers 2004: 309). The Chancellor, Winston Churchill, was not concerned with the morality of gambling. His priority was to balance the budget without raising income tax or resorting to protectionist measures. This was why he had introduced a Betting Duty in 1926, a measure which would bring at least some $£ 6,000,000$ in revenue, or so it was hoped. Such a scheme, however, was regarded with great suspicion by the Home Secretary, Joynson-Hicks. "Jix", a self-confessed "Puritan Home Secretary," lifelong teetotaller and anti-gambler, considered taxation or even the regulation of gambling as state approval of a sinful activity, an inducement to crime. The Home Office was therefore opposed to any relaxation of the law on betting and gambling, whereas effective taxation could only be based on legal activities. The divergence between these ministers encapsulates the stalemate in the search for a satisfactory policy on gambling in the interwar years. The resulting status quo in the criminal law led to the predictable fiasco of the Betting Duty, as the Treasury had grossly underestimated the extent of illegal betting. Even in its best year (1927-28) the duty only produced $£ 2,700,000$, and it was scrapped in 1929 (Dixon 1991:269-297). With the persistent, although declining as we will see, influence of moralist and paternalist views on working-class gambling and leisure, the legalisation of street betting, the illegal elephant in the room, remained an unrealistic prospect for another generation. However, two major developments brought the issue of gambling back on the legislative agenda. The first was the emergence of commercial greyhound racing. The second was the Irish Hospital Sweepstake, a foreign lottery inaugurated in 1930 and extremely successful in Britain, where lotteries had been banned for more than a 
century. A Royal Commission on Lotteries and Betting was set up in 1932 to deal with what many contemporaries presented as "a grave social menace." The Betting and Lotteries Act, passed in 1934, reinforced the clampdown on the "Irish Sweepstake" and ruled out the alternative of reviving a national lottery in Britain, either for good causes or for the Exchequer. This can be regarded as the last victory of the anti-gambling movement in Britain, but a closer analysis of the debates and provisions reveals a weakening of its influence. What was achieved was an awkward compromise due to the unexpected convergence between the moral concerns of traditional pressure groups and the determined lobbying of commercial interests. An evolution of public perceptions is also noticeable, confirming the gradual acceptance of betting as a nonreprehensible leisure activity for male working-class adults, and, perhaps more surprisingly, for women. The present article seeks to provide an overview of this evolution, mainly by drawing on previous research but with new insights into the debates surrounding the passing of the Betting and Lotteries Act.

\section{The ubiquity of illegal betting}

2 The popular television series Peaky Blinders, first broadcast in 2013, is largely based on the porosity between legal and illegal betting in the 1920s, the former often serving as a cover for the activities of criminal gangs. Unobtrusive allusions in contemporary cinema, like a brief exchange (a few seconds) between the street bookie and the policeman on the beat in Passport To Pimlico, one of the great box-office successes of 1949, provide telling evidence of the ubiquity of this phenomenon until the legalisation of betting-shops in 1961. The concision of this dialogue, and similar examples in other Ealing comedies and numerous press-cartoons, show that this "underground" reality was familiar territory to mass audiences. Screenwriters and cartoonists did not have to labour the point.

3 Although no further explanation was needed at the time, a brief historical reminder is required to understand these allusions now. In the second half of the $19^{\text {th }}$ century, concern about gambling had increasingly focused on sports betting. This was mainly due to the spectacular growth of horse racing and the increased availability of betting opportunities. Betting on horses was no longer confined to punters at the racetrack or gentlemen in their clubs. It could be practised by the urban masses, thanks to the development of commercialised pub-based betting in London and other cities. This innovation had rapidly been banned by the Betting Act 1853, which remained the basis of betting legislation until 1960. The use of any house, office, room or other place for receiving cash betting was declared illegal. The measure was clearly announced as a paternalist attempt to deal with working-class gambling (Dixon 1991:39); therefore the prohibition applied mainly to cash betting away from the racecourse (off-course cash betting), the only form of betting available to the majority of the population. It did not apply to betting among members of a club, or to credit betting by correspondence, but this required a respectable address, a bank account, and preferably a telephone. It was still legal to bet in cash on the racecourse, but working-class access to legal betting facilities had been significantly reduced with the closure of many racecourses around London in 1879. This class-discriminatory dimension, which had always been resented, aroused even more hostility in the post-1918 age of universal franchise. 
4 Moreover, the prohibition of cash betting had failed to prevent the expansion of popular betting, on which there is now a substantial scholarly literature. After 1853, bookmakers simply moved their operations to the street, although betting houses continued to operate in some regions (Clapson 1992:24-49; Dixon 1991:43-5). In the 1880 s, betting and sporting news became indispensable weapons in the circulation wars of the "new journalism" and the popular press, providing the small punter with reliable information. Average odds at the start of the race (starting prices) were published in the press and served as a national norm for the settlement of winning bets. Illegal transactions could therefore be quietly carried out without lengthy negotiations (Stevenson 1984:384-6). Despite the reinforcement of repression voted by Parliament in 1906, street betting became "one of the most distinctive features of English town-life, observable to anyone" (McKibbin 2000:372; Chinn 1991). A sophisticated underground economy developed, with a network of lookouts and "bookies runners". This led to a considerable level of police corruption, stage-managed arrests being part of the arrangement. It has been argued that this amounted to "an unofficial kind of administrative regulation, with bribes and fines serving as licence fees" (Dixon 1991:224). By 1914, betting on horse races had become "one of the most common leisure British activities" (Huggins 2000:232) among British males and the vast majority of bets were illegal.

5 The fact that prohibition had proved unworkable led to a radical change in police attitudes (Dixon 1991:198,258). In pre-war investigations (Royal Commission on the Duties of the Metropolitan Police 1908), the level of police corruption had been dismissed as insignificant; the standard response being that it was confined to a few "bad apples." In 1911, when it became apparent that the 1906 Street Betting Act had failed to eradicate illegal gambling, the Metropolitan Police Commissioner had merely advocated more stringent measures, echoing the views of the Anti-Gambling League (Dixon 1991:131-5). After the war, on the contrary, police representatives heard by various parliamentary enquiries (Select Committee on a Betting Duty 1923 (henceforth SC 1923); Royal Commission on Police Powers and Procedure 1928-1929; Royal Commission on Lotteries and Betting 1932-33 (henceforth RC 1932-33)). were unanimous in saying that prohibition could not be enforced when the public saw no moral distinction between betting at Ascot (which was legal) and betting in the street (which was not). As this brought the law into disrepute, most of them were in favour of administrative regulation. Their case was reinforced by the reduction in drinking and drunkenness. Wartime controls had continued in peacetime thanks to the Licensing Act 1921, and drink offered a "lesson in control" which could be favourably contrasted with the poor record of prohibition in the US. However, in a Memorandum submitted to the 1923 Select Committee, the Home Office rejected the views of the police: "It is an undoubted fact [...] that a very large proportion of offences of dishonesty [...] are attributable to excessive betting. No statistics are available in support of this proposition. Certainly there are no statistics which contradict it" (Dixon 1991:194-5). Building on this circular reasoning, it was then argued that legalization would increase working-class betting. It was conceded that eradication could not be achieved but preserving the status quo would at least ensure its containment. Accordingly, the Street Betting Act was not repealed, which is the main reason for the failure of the Betting Duty, as David Dixon has demonstrated. Plans to replace it with a licensing system were scrapped in 1929 by the incoming Labour government, whose Chancellor, Philip Snowden, shared the views of Joynson-Hicks. 


\section{A disruptive newcomer. the "Tote" and its imitators}

6 mutuel, or pool betting. The Jockey Club had requested that the proceeds of the Betting Duty should contribute to the improvement of horse breeding and racing. The request was refused, but instead, the Racecourse Betting Act 1928 established a system of cash pool betting dedicated to that purpose and operating exclusively on the racecourse.

7 Pari-mutuel consists of a pooling of the stakes, which are divided among the winners once the operating expenses and commission have been deducted. Pool betting was a relative novelty in Britain, where commercial betting was controlled by bookmakers, who relied exclusively on fixed-odds betting, a contract in which the amount of the winnings is fixed in advance. The implementation of this innovation on a large scale was facilitated by the invention of a new system, the "Totalisator", presented to a parliamentary committee in 1926, which could calculate large numbers very quickly, and was more reliable than previous systems. The "Tote", as it came to be known, was controlled by an official body, the Racecourse Betting Control Board (RBCB), whose members were appointed by the government, the Jockey Club and other racing organisations. Racing circles had long been interested in pool betting, hoping that it would both subsidise the sport and drive the bookmakers out of the racecourse. The Tote, however, was a qualified success, and never threatened the dominant position of bookmakers and fixed-odds betting on horse racing. But the indirect involvement of the government gave a certain legitimacy to betting, the very thing that anti-gamblers feared. As the Christian Social Union put it a few years later, Government representatives should be "withdrawn from the Board" to which they gave "undesirable prestige" (RC 1932-33 paragraph 400).

The special status of horse racing in British society protected the Tote from serious controversy, but this was not the case when pool betting developed in less prestigious sports like dog racing and football. Dog racing was not a new sport. It had a cross-class following, ranging from the aristocratic patrons of "coursing", where greyhounds chased a live hare, to whippet racing in mining communities, usually in pursuit of a rabbit or an artificial bait. But in the mid-twenties, the invention of the electric hare opened up new opportunities and led to a spectacular rise in commercial greyhound racing (Clapson 1992: 138-61). In 1925, a company (The Greyhound Racing Association (Manchester) Limited) was registered in Manchester with enough capital to establish a large stadium catering for 25,000, starting its operations in 1926. Within a year, 62 greyhound race companies were registered at a total capital of $£ 7$ million. Attendances reached 8 million in February 1929, twice the number recorded in April 1927 (Miers 2004:308). By December 1932, 187 tracks were in operation, rising to 220 one year later (RC 1932-33, paragraph 142). There were now more greyhound tracks than racecourses, and the discrepancy was even larger for fixtures. In Greater London, for instance, 4,000 greyhound fixtures were organised each year within 15 miles of Charing Cross against 187 for horse racing. In 1931, paid attendances at tracks licensed by the National Greyhound Association Racing Club, which represented only half of the total, amounted to $18,000,000$. Contrary to Joynson-Hicks's prediction in November 1928 that "it wouldn't last" (Miers 2004:308), the popularity of greyhound racing continued to rise and reached a climax in the late 1940s. Several factors can explain this success. Most 
tracks were located in densely populated urban districts. Meetings took place on a daily basis, in the evening, after work, unlike horse racing which took place in the afternoon. Being more accessible, the dog track had in effect become "the poor man's racecourse," where one could bet in cash without breaking the law.

The sudden emergence of commercial greyhound racing revived the traditional arguments against popular gambling, with an increase in anti-racing literature after 1927. As the National Anti-Gambling League was now a declining force, the impetus came from the Protestant churches, with the creation of a National Emergency Committee of Christian Citizens in December 1927. These views dominated press discourse, although they only represented a minority of the population. By May 1928 the Home Secretary had received over 1,600 motions from religious and secular organisations, as well as a cross-party deputation of MPs pressing him to take action. Tracks were described as "canine casinos", a "social evil" creating secondary poverty by encouraging excessive gambling (Huggins 2007:113-4). A particular concern was the need to protect women and the young, with regular complaints that young women and "girls of tender years" had been seen betting on the dogs. These arguments had been used against horse racing in the previous century, but other attacks came from those who considered that unlike horse racing, dog racing was not a real sport, but simply a vested interest supporting gambling. Churchill himself, a keen horseman in his youth, dismissed the dog tracks as an "animated roulette," but his attitude smacked more of class prejudice than moral concern.

What proved most contentious was not the presence of bookmakers at dog tracks, but the introduction of pari-mutuel, or tote betting, on greyhound racing tracks in the wake of a House of Lords ruling. Under the 1928 Racecourse Betting Act, the tote was supposed to be the monopoly of horse racing fixtures. Besides, the case used as a precedent (Attorney General v. Luncheon and Sports Club (1929), A.C. 400) was unrelated to greyhound racing, and merely intended to prove that a club organising pari-mutuel betting was not a bookmaker, and therefore not liable to betting duty. However, after a first experiment which survived a court challenge in 1929, the number of "greyhound totes" had reached 130 by the end of 1932. Such a development was bound to increase the hostility of anti-gamblers. Under the Act of 1928, the proceeds of the tote were allocated to the support of horseracing. As we have seen, the status of dog racing as a sport was much more controversial. In addition, the proceeds of the greyhound totes were entirely pocketed by the organisers or served to lower entrance fees. There was not even a semblance of a good cause.

Opposition to greyhound totes was not confined to anti-gambling ginger groups, its legality was questioned by bookmakers, who regarded pool betting as unfair competition. The Leeds Greyhound Racing Association was taken to court by a bookmakers association and lost in appeal in December 1932. It was now confirmed that greyhound totes had no legal basis. However, the government was still reluctant to act, for fear of being accused of applying double standards for dog tracks and racecourses. Besides, the major greyhound companies cultivated an image of respectability, with a National Greyhound Racing Club emulating the Jockey Club and a Greyhound Racing Totalisator Board (set up in October 1931) (Roudaut 1997: 287) modelled on the RBCB, the controlling body of the official racecourse totalisator.

12 A more serious moral panic derived from another controversial effect of the House of Lords ruling: the development of the so-called Tote Clubs. In October 1931, a company, 
Pool (Tote) Clubs Limited, had exploited the same legal loophole to open a chain of clubs with a nominal membership fee (a shilling for a year). Membership gave a right of entry to all clubs in the chain, originally six in London, spreading rapidly to 32 throughout the country. Similar initiatives mushroomed within a few months. In December 1932, 284 tote clubs had been created. Members could bet on horse races in the afternoon and dog races in the evening, which to critics was conducive to continuous, and probably excessive, betting. Moreover, since the organiser of a pool was not regarded as a bookmaker, bets could be taken in cash. In other words, these new "gambling hells" were creating a situation similar to the proliferation of betting shops in mid-Victorian London. This flew in the face of the 1853 Betting Act, the fountainhead of betting legislation, which prohibited betting shops.

\section{The Irish Hospitals Sweepstake and the Royal Commission}

13 The development of tote clubs prompted widespread condemnation when it came to public notice in the last months of $1932,{ }^{1}$ but another basis of gambling legislation was already being challenged, and it was this, rather than the fate of the tote, which led the government to set up a Royal Commission in April. In 1930, The Irish Free State had authorised the Irish Hospital Trusts to raise funds by organising sweepstakes on classic British races (usually three, including the Epsom Derby and the Grand National). In fact, this sweepstake amounted to a lottery since punters bought a numbered ticket. A few days before the race, a draw paired competing horses with specific numbers. All tickets with a number matching a horse received a prize, the highest prize being awarded to the ticket matching the winning horse. By the end of 1933, 27 million pounds had been raised and it was estimated that two thirds of the tickets had been bought in Britain (Coleman 2009). The problem was that lotteries, especially foreign lotteries, had been banned in Britain since 1826. The law was being flouted on a massive scale for the benefit of a foreign country. The main attraction lay in the amount of prize money, with the first prize culminating at $£ 350,000$ in the second sweepstake. ${ }^{2}$ Publicity was provided by the coverage of the results in the British press, while reports on the derisory penalties incurred by offenders proved more of an incentive than a deterrent. Questions were raised in parliament and a private member's bill proposed the creation of a national lottery similar to the "Irish sweepstake", the proceeds of which would fund good causes in Britain. The bill was rejected, but shortly afterwards the government set up a Royal Commission whose remit included the burning issues of lotteries and tote betting. An interim report devoted to tote betting was published in January, shortly after the court case which had confirmed the illegality of greyhound totes. The final report was submitted a few months later, in June 1933. It was more usual for a Royal Commission to sit for two or three years, and the speed of the proceedings in this case reveals a sense of urgency.

To a large extent, the recommendations of the Royal Commission pointed to a tightening of the existing law. Concerning the Irish Sweepstake, stakes intercepted by the Post Office should be confiscated, instead of being returned to the sender. It was also assumed, wrongly, that the Irish Sweepstake would be a short-lived phenomenon, an assertion which was contradicted by other parts of the report. Above all, proposals for a National Lottery, which had prompted the setting up of the Commission, were 
firmly rejected. The feasibility of such a scheme was not in doubt, but it was asserted that it would have serious social consequences on the poorest sections of the community, deluded by the prospect of large prizes. ${ }^{3}$ A National Lottery for good causes was considered even less advisable than a Lottery funding the Exchequer, because of the probable competition between various deserving causes and the likely fall in traditional methods of fund-raising. British hospitals, it was argued, were likely to be worse off in such a system. Furthermore, a National Lottery for good causes would create a "confusion of motives, a most insidious method of encouraging the gambling habit" (ibid, paragraph 444). The only positive change concerned raffles and small lotteries, which were merely tolerated by local authorities. It was recommended to legalize them, but under strict conditions (small stakes, small prizes, and charitable or local purpose).

When it came to tote betting, the repressive tone was even more pronounced. Private operators were often suspected of opaqueness, especially in the amount of their commissions and deduction of costs. ${ }^{4}$ Above all, tote clubs were accused of increasing the amount of gambling, whereas official policy was its containment. The standard defence of proprietors was that their establishments were merely diverting punters from illegal street-betting, but this was strongly rejected in the report: "Much ingenuity had been spent in the provision of modern facilities [such as] telegraphic or telephonic communications with the racecourses," which rendered tote clubs "much more attractive than the betting houses of 1853 " and made gambling "more seductive." A parallel was made with the Irish Sweepstake, which had created a habit among people who had previously "felt no desire to participate in mammoth lotteries". Likewise, betting facilities at greyhound tracks or in tote clubs had been "not so much the means of meeting an existing demand, as the instrument for fanning and encouraging a latent propensity" (RC 1932-33, paragraph 207). The Commission was therefore clearly in favour of the prohibition of tote clubs and dog totes. It was stated that the organisers of a racing fixture should have no financial stake in betting on their tracks. Therefore, tote betting should be strictly limited to racecourses for the benefit of horse racing, as provided by the Racecourse Betting Act. Severe restrictions were also advocated for the frequency of fixtures in dog racing ${ }^{5}$ and the number of races in each fixture. Other recommendations aimed at limiting the creation of new tracks.

\section{Shifting attitudes and legal stagnation: the 1934 Act}

The report was greeted with satisfaction by anti-gambling associations and religious figures, especially in the Nonconformist churches. The Home Office announced the drafting of a bill along these lines. Indeed the Betting and Lotteries Bill introduced in the spring of 1934 included some of its recommendations. The prohibition of lotteries, including foreign lotteries, was confirmed, with the exemptions suggested in the report. A provision clearly aimed at the Irish Sweepstake made it easier to obtain search warrants in connection with a lottery and to use force if necessary. The number of fixtures in greyhound racing was considerably curtailed. In some cases, the bill went even further than the recommendations. The age of legal betting was raised to 18 , instead of the suggestion of the report to raise it from 16 to 17. Hard-line views also prevailed on the intractable issue of street betting, the only one on which the commission had distanced itself from anti-gambling views. Its report had noted the 
failure of the Act of 1906, which, "by allowing credit betting but not [cash] betting, [was] unfair to the working man and represented 'class legislation'." (RC 1932-33, paragraph 279). The legalisation of postal cash betting was presented as the best alternative. It was concluded that the Street Betting Act could not be effectively enforced without "the addition of some further facility for [cash] betting, whether or not postal cash betting," (ibid, paragraph 311) but this call for a partial relaxation of the prohibition was not acted upon. The government had opted for the preservation of the status quo.

What is remarkable, however, is the great difficulty with which the bill was passed, in spite of the impressive majority of the Coalition government, more than 500 MPs. It took several weeks of debate and extreme pressure on the government backbenchers to secure its passing in November. The second section of the text, which dealt with lotteries, was so controversial that the government was forced to impose a whip on some occasions. The most serious attacks came from members of the Conservative Party, which was the leading partner in the coalition. Churchill, who had been relegated to the backbenches since 1929, took an active part in a rebellion against what he described as "class legislation of a most objectionable character" (The Manchester Guardian, Tuesday November 13, 1934: 6 [Roudaut 1997: 327]).

These tensions reflected changing attitudes to popular leisure, crossing party lines as well as class boundaries. Churchill, like many of his colleagues, would have preferred the Tories to govern on their own and resented a policy inspired by the junior partner in the coalition, the National Liberals. Indeed, anti-gambling views, like the temperance movement, found more supporters among the Liberals than among the Tories, despite notable exceptions such as Joynson-Hicks. As for Labour, it had traditionally been led by committed anti-gamblers, who had often begun their public careers as temperance workers or lay preachers. This did not prevent Churchill from calling on the Opposition to join him in the "defence of the rights of ordinary men". Significantly, a number of Labour MPs expressed similar views on the harmless character of staking a few pence on a sweepstake or a lottery, even though the party leadership sided with the government on this issue. This evolution was not confined to parliament. If the Laboursupporting Daily Herald, which had increased its circulation to 2 million in 1933, was studiously neutral in its reporting on the debates, it was also happy to publish the results of greyhound races as well as advertisements for football pools (Daily Herald Nov.13, 1934:2; ibid, Nov.12, 1934:17). Labour voters and activists were no longer, if they had ever been, unanimous in their condemnation of all forms of gambling as a sinful activity and an opiate for the masses. ${ }^{6}$ A more relaxed view of commercial leisure could now be voiced in a publication largely owned by the TUC.

It was also pointed out that some restraints on press freedom bore similarities to another government bill strongly opposed by Labour, the Incitement to Disaffection Bill, largely prompted by worries about pacifism, communism and fascism, and better known as the Sedition Bill. One of the most contentious clauses was a ban on the publication of all sports results related to the Irish sweepstake or another lottery, which aroused much derision and prompted Churchill to quip that Irish newspapers might have to be banned in Britain. This was withdrawn, as well as the possibility to prosecute the individual buyer of a lottery ticket. The final version provided that only sellers and organisers could be fined or imprisoned, and that the onus of the proof would lie on the prosecution. These concessions show that much of the debate had 
moved away from a paternalist concern for the working class to focus on the infringement on civil liberties.

Attitudes had also changed at Whitehall, as David Miers' study of departmental archives has shown (Miers 2004: 308-14). Home Office internal documents abounded with dismissive comments on the prejudice and sweeping generalisations to be found in anti-gambling propaganda. Since the 1920s, most officials had cautioned against hasty action against greyhound racing.

Another factor was the bookmakers' search for respectability. In an attempt to eliminate violence and intimidation by gangs from the racecourses, ${ }^{7}$ their associations had formed Pitch Committees and reached an agreement with the Jockey Club and the police in 1929. Allocation of pitches was now subject to approval by racecourse management, under Jockey Club's jurisdiction. Despite sporadic outbreaks, racecourse violence subsided considerably in the following decade. This evolution led to the recognition that official engagement with the bookmakers' commercial interests was a "necessary condition of effective regulation" (Miers 2004: 284). A further step was taken in 1932, when regional organisations decided to confederate and form a National Bookmakers Protection Association (NBPA) in order to lobby more effectively against competition from the Tote.

Other commercial interests were to play a significant part. A striking feature of the government bill lay in the concessions made to the greyhound-racing and football pools operators, who were allowed to continue their tote or pool-betting operations, contrary to the recommendations of the report. Such leniency contrasted sharply with the government's intransigence on lotteries. Despite pointed questions and strong reactions in parliament, the Home Secretary refused to explain why a clause making football pools illegal had been deleted from the original text. In fact, this was partly due to the changes mentioned above, but also to a carefully orchestrated campaign of corporate lobbying. A Pools Promoters Association (PPA) was created shortly after the publication of the bill and intervened discreetly to avoid a ban on football betting. A similar move on greyhound totes had been anticipated since the recommendations of the Royal Commission. Within days of the publication of its interim report, the National Greyhound Racing Society had published a rebuttal of its arguments and launched a high-profile protest campaign. Memoranda were sent to the Home Office pointing out implications for local communities and employment. In an interview with the Times (11 January 1932), its secretary had called the report “a bookmaker's charter, presented by an anti-gambling commission". He had a point: the bookmakers had a vested interest against greyhound totes, which they rightly saw as an attempt to undermine their activities. This was, as we have seen, the main reason behind the creation of the NBPA. Indeed the test case confirming the illegality of greyhound totes had been brought by bookmakers who feared a tote monopoly. While the rivalry between bookmakers and pari-mutuel operators had a long history, with violent incidents before the war, the occasional convergence between moral campaigners and the commercial interest of a section of the betting industry was not new. It was alleged, for example, that in reprisal against Churchill's Betting Duty, bookmakers had supported the anti-gambling Labour Party in the 1929 General Election (Dixon 1991:296).

Moreover, as pointed out by Mike Huggins, the more select greyhound tracks had a cross-class appeal and cultivated their respectability. Like the enclosed racecourses of the late nineteenth century (Roudaut in Pickard 2014:239-250), they were heavily 
capitalised and needed to secure their profitability by differential pricing and the provision of numerous amenities catering for the middle classes, at least before 1939 . For a few years, there was an aura of modernity in the larger tracks, with their floodlights, a novelty not found at other sporting venues, music and a carefully orchestrated pageantry, including the presence of celebrities to provide glamour (Huggins 2007:104-6). The proletarian image of greyhound racing was only partly accurate, but it was deliberately emphasised to denounce a class-discriminatory ban, a theme which was conveniently relayed in the press, including the Economist and the Daily Telegraph.

The social and economic background of the main actors also played a part. The leading dog-tracks owners were affluent and well-connected businessmen. Some board members of the National Greyhound Racing Society also sat in the Commons or the Lords and were able to defend their interests in parliament. At any rate, the views of the betting industry, despite the occasional scathing remark in the Times or the Manchester Guardian, were relayed by the press to an extent which would have been unthinkable before the war. Once a pariah, the betting industry was gradually becoming part of the mainstream leisure industry. In this context, official advice went against upsetting the fragile balance between rival pressure groups, as evidenced by this note written for the Home Office two years before the first reading of the bill:

I am strongly opposed to getting further involved [...] The Home Office has nothing whatever to do with improving breeds of horses nor is it the business of government departments to favour totes as against bookmakers [...] The general policy is for the Home Office not to move legislation on betting and gaming (except concerning children) and to block what disturbs the status quo [...] The various interests should be left to fight it out among themselves (Miers 2004:310).

\section{Conclusion}

Although it was intended to provide a comprehensive overhaul of betting legislation, the most striking aspect of the Betting and Lotteries Act 1934 is how little was achieved. ${ }^{8}$ This was politely acknowledged in an official report published in 1951: "The law relating to betting, lotteries and gaming, except for modern legislation covering only a small part of the field, is obscure, illogical, and difficult to enforce. [...] In most respects, therefore, the law to- day does not differ from the law as it was in 1933" (RC 1949-51, paragraphs 10\&12). Following a Royal Commission set up in reaction to the creation of the Irish Hospital Sweepstake and the development of commercial greyhound racing, the reform of 1934 had overlooked the most widespread form of illegal betting, leaving the central issue untouched. It could also be argued that the errors made with street betting in 1906 were repeated with the repressive strategy chosen to deal with the Irish Sweepstake. In the first place, official intransigence did not dispel the impression that there was one law for the rich and one for the poor. Shortly after the passing of the law, the Daily Herald noted that if proposals for a national lottery had been rejected, private ones remained legal, including the socially exclusive Stock Exchange Sweep and the Baltic Sweep, which offered very large prizes (Daily Herald, 15 Nov. 1934:6). Above all, and despite an increase in the judicial arsenal, the punitive approach proved similarly ineffective. In 1932, the royal commission observed a "widespread disregard of the law as to lotteries" which had "brought this branch of the law into contempt". There was a risk that "contempt for one branch of the law [would] breed a general contempt for the 
law in general". The solution recommended to bring this to an end was a strengthening of repression, although it had proved useless against street betting. Indeed, according to a previous report published in 1923, the Street Betting Act of 1906 had not prevented "the continual breaking of the law by millions of people," which could "establish a general weakening of respect for the law" (SC 1923, paragraph 15, quoted by Roudaut 1997: 332). The obvious analogy had not dissuaded the government from repeating a failed strategy. As with street betting, magistrates were often reluctant to prosecute for the new offence. Moreover, the rising tide of unemployment in the 1930s provided an army of easily replaceable ticket dealers. Even in a period of full employment, as the London Police Commissioner acknowledged some fifteen years later, "it [was] not too difficult to get a ticket in the Irish Sweep if you want[ed] it" (RC 1949-51, paragraph 136:39). If a drop was observed in the receipts of the Irish Hospitals Trust after 1934, it was probably due to the rising popularity of the football pools, whose annual turnover was estimated to have jumped from $£ 8$ million in 1933 to $£ 22$ million in 1938 (ibid, paragraph 110). By the late 1930s, an estimated 10 million coupons were filled in each week. In fact, the emergence of alternative betting facilities proved more effective than prohibition, and it may be more illuminating to regard the 1930s as a watershed rather than a period of stagnation. Ostensibly, the official stance on lotteries may be seen as a victory for anti-gamblers, but it was the last one, and its significance was undermined by concessions to tote and football pools operators. More momentous was the signal sent by the intensity of the debates and the change in the nature and extent of press coverage. This was confirmed two years later when the Football Association (FA) launched the so-called "Pools war" (Huggins 2013:44, 99-119). In an attempt to drive the pools companies out of business by preventing them from publishing their weekly coupons in time, the FA refused to disclose the fixture lists until two days before the match. The public outcry was so massive that the FA had to back down very rapidly. ${ }^{9} \mathrm{~A}$ few weeks later, a private member's bill seeking to ban the pools also suffered a crushing defeat, while several Labour MPs joined their Conservative colleagues in calling for a more tolerant approach and less interference with recreational pursuits. This time, Labour dissenting voices were more outspoken than in 1934. One of them openly criticised his former party leader, George Lansbury, for "assuming a superior morality and assuming that they knew a great deal better than the working people" (Hansard, HC. Deb. 03 April 1936, c. 2884). This bluntness reflected the strength of public reaction to the FA's short-lived initiative..$^{10}$ Likewise, antigambling views were increasingly marginalised in the press, where the controversy gave rise to an unprecedented amount of discussion on the pools. As Huggins puts it, this coverage "reemphasized that they were perhaps the greatest leisure phenomenon of the decade, and a major part of British social life". It was stressed that the supposed "social effects" of betting, especially self-inflicted poverty, could not apply to a few pence spent each week on the pools. Moreover, the weekly interval precluded any suspicion of continuous or compulsive betting. The same was true of allegations of corruption since organisers had no financial interest in match fixing, given the nature of pool betting. In fact, far from destroying the pools as intended, the events of 1936 enhanced their status in British society. This would benefit the betting and gambling industry as a whole. A point of no return had been reached, which had a clear impact on later governmental initiatives, in keeping with the fading of religious Nonconformity as a force in British public life (including Liberal and Labour politicians). All subsequent reforms would tilt towards liberalisation. Even if they were rejected at the time, many 
of the arguments rehearsed by the Royal Commission and during the debates of 1934 would resurface to justify the creation of Premium Bonds in 1957, the legalisation of betting shops in 1961, and the launch of the National Lottery in 1994.

\section{BIBLIOGRAPHY}

Attorney General v. Luncheon and Sports Club (1929), A.C. 400.

“M.P.s’ Revolt Against Betting Bill Grows.” Daily Herald, November 13, 1934: 2.

“Reading Dog Wins Puppies' Final At Wembley.” Daily Herald, November 12, 1934: 17.

"Legal experts were last night prophesying a flood of law suits over the Betting and Lotteries Act." Daily Herald, 15 November 1934: 6.

Hansard, HC. Deb. 03 April 1936, c. 2884.

Royal Commission on the Duties of the Metropolitan Police 1908.

Royal Commission on Police Powers and Procedure 1928-1929.

Royal Commission on Lotteries and Betting 1932-33.

Report of the Royal Commission on Betting, Lotteries and Gaming 1949-1951. London: HMSO, 1951.

Select Committee on a Betting Duty 1923 Royal Commission on Police Powers and Procedure 1928-1929.

The Manchester Guardian, November 8, 1934: 3.

Burns, John. Brains Better than Bets or Beer: The Straight Tip to the Workers. Clarion Pamphlet, $\mathrm{n}^{\circ} 36$, 1902.

Chinn, Carl. Better Betting With a Decent Feller. Hemel Hempstead: Harvester Wheatsheaf, 1991.

Clapson, Mark. A Bit of a Flutter: Popular Gambling and English Society, c. 1823-1961. Manchester: Manchester UP, 1992.

Coleman, Marie. The Irish Sweep: a History of the Irish Hospitals Sweepstakes, 1930-1987. Dublin: U. College Dublin P., 2009.

Dixon, David. From Prohibition to Regulation: Bookmaking, Anti-Gambling and the Law. Oxford: Clarendon Press, 1991.

Hilton, John. Why I Go In For the Pools. London: Allen \& Unwin, 1936.

Huggins, Mike. Flat Racing and British Society 1790-1914. London: Frank Cass, 2000.

Huggins, Mike. “'Everybody's Going to the Dogs”? The Middle Classes and Greyhound Racing in Britain Between the Wars." Journal of Sport History 34 (4) Spring 2007: 401-421.

Huggins, Mike. "Association Football, Betting and British Society in the 1930s: The Strange Case of the 1936 'Pools War'." Sport History Review 44 (2), 2013: 99-119. 
Laybourn, Keith. Working-Class Gambling in Britain, c. 1906-1960. The Stages of the Political Debate. Lampeter: Edwin Mellen Press, 2007.

McKibbin, Ross. Classes and Cultures: England 1918-1951. Oxford: Oxford UP, 2000 [1998].

Miers, David. Regulating Commercial Gambling. Oxford: Oxford UP, 2004.

Orwell, George. The Road to Wigan Pier. 1938.

Roudaut, Emmanuel. "Les Controverses sur le jeu dans la société britannique (1890-1961): le cas des paris sportifs". Unpublished Ph.D dissertation, Université Lille 3, 1997.

Roudaut, Emmanuel. “'Roughs on the Turf' and 'Suburban Saturnalia': Anti-Social Behaviour on Victorian Racecourses”. In Anti-Social Behaviour in Britain. Ed. Sarah Pickard. London: Palgrave Macmillan, 2014. 239-250.

Stevenson, John. British Society 1914-45. Harmondsworth: Penguin Books, 1984.

\section{NOTES}

1. Concern (and press coverage) grew after the summer, when the number of tote clubs increased dramatically (25 at the end of June 1932, 284 on December 10).

2. It was subsequently capped at $£ 30,000$.

3. "These large prizes are a dazzling lure to the ordinary man or woman. To all but a few thousand people in this country, a sum of, say, £30,000 seems to offer a transformation of their lives. [...] Lotteries appeal with especial force to those in straitened circumstances, and to those in economic insecurity, since they hope to gain financial stability by winning a prize." RC 1932-33, paragraph 455.

4. Some Pool Promoters had been involved in scandals. One, prosecuted in Edinburgh in 1930, had been found to be taking a total commission of 77 per cent. Another case would find a commission of 34 per cent. But the main organisations claimed to limit their profit to 5 per cent of the total income. See Hilton (1936: 8-9).

5. 10 a month, 100 a year.

6. For a classic articulation of anti-gambling socialism, see Burns (1902). For an overview of Labour's evolution on gambling and teetotalism, see Dixon (1991: 72-81). See also Laybourn (2007).

7. These "gang wars" form the backdrop to the television series Peaky Blinders, already mentioned.

8. Ironically, the law was passed shortly after the repeal of prohibition in the United States, with the adoption of the $21^{\text {st }}$ Amendment in December 1933, and the creation of the Loterie nationale in France in July 1933.

9. George Orwell has written a famous description of popular reactions to this initiative: "I happened to be in Yorkshire when Hitler re-occupied the Rhineland. Hitler, Locarno, Fascism, and the threat of war aroused hardly a flicker of interest locally, but the decision of the Football Association to stop publishing their fixtures in advance (this was an attempt to quell the Football Pools) flung all Yorkshire into a storm of fury." (Orwell 1938:81).

10. MPs, journalists and football clubs received a substantial number of letters on the subject. Most of them were in support of the pools. See for instance a sample published by the presenter of weekly Broadcast Talks on the BBC (Hilton 1936). 


\section{ABSTRACTS}

In Britain, paying upfront to place a bet on a horserace, or any other sporting event, was illegal until 1961. Although it lasted more than a century, this prohibition, frequently condemned as socially discriminatory, proved rapidly unenforceable. Large-scale networks of underground betting prospered, with attendant police corruption. The uneasy balance achieved by the combination of repression and implicit arrangements between lawbreakers and law enforcers was seriously disrupted by three simultaneous developments during the 1930s. The rapid growth of commercial greyhound racing and football pools, combined with the launching of an Irish lottery based on British horsing racing, was highly controversial and led to a tightening of betting laws in 1934. However, the very premises of prohibition were openly questioned during the parliamentary debate, in a context of economic depression and universal suffrage. Dissent came from both sides of the House and was extensively covered by the press. Moreover, some sections of the betting industry had improved their public image and increased their economic and political leverage, which enabled them to obtain significant concessions. Antigambling groups, once so influential, were now put on the defensive, although their moral concerns could occasionally converge with the economic interests of some sport-betting entrepreneurs. Thus, the rejection of a national lottery cleared the way for the expansion of football pools, which facilitated the continuation of the ban for another sixty years by providing a viable commercial alternative. Ostensibly, the compromise of the 1930s was the last great victory of anti-gambling agitation in Britain, but it dented a fragile and ambivalent status quo and sowed the seeds of the liberalising laws of the late twentieth century.

Instituée au siècle précédent, la prohibition des formes les plus populaires de paris sportifs perdura jusqu'à la seconde moitié du XXe siècle au Royaume-Uni. Perçue comme une législation de classe, cette prohibition s'avéra rapidement inapplicable. Une économie souterraine se mit en place à grande échelle, au prix d'une forte corruption policière. Cet équilibre instable entre répression et accommodements fut bouleversé par certaines innovations de l'entre-deuxguerres. Le développement simultané des courses de lévriers, des football pools et d'une loterie irlandaise prenant pour support les courses de la saison hippique anglaise suscita de vives polémiques ainsi qu'un durcissement de la législation en 1934. Certains aspects fondamentaux de la prohibition furent toutefois ouvertement remis en cause dans les débats parlementaires de l'époque. Dans un contexte politique transformé par le suffrage universel et la crise économique, ces tensions, qui transcendaient les clivages partisans, trouvèrent un écho sans précédent dans l'opinion et dans la presse. S'y ajoutait le pouvoir accru de certains secteurs de l'industrie du jeu, tant sur le plan économique qu'en matière d'image, ce qui conduisit le gouvernement à faire des concessions sélectives. Les ligues de vertu, dont l'influence avait été déterminante depuis un demi-siècle, se retrouvèrent ainsi sur la défensive, mais les intérêts corporatistes des uns pouvaient converger avec les préoccupations morales des autres. Ainsi, par exemple, l'idée d'une loterie nationale fut écartée jusqu'à la dernière décennie du siècle, mais le maintien de cette interdiction fut facilité par l'existence des football pools, qui remplissaient une fonction analogue dans un cadre purement commercial. Si le compromis des années trente semble constituer la dernière victoire du rigorisme en matière de législation $\mathrm{du}$ jeu, il ne fit que remodeler un statu quo ambigu et portait en germe la libéralisation de la fin du siècle. 
INDEX

Mots-clés: loteries, paris, sport, Irish Sweepstake, tote clubs, courses de lévriers, Royaume-Uni Keywords: lotteries, betting, sports, Irish Sweepstake, tote clubs, greyhound racing, United Kingdom

\section{AUTHOR}

\section{EMMANUEL ROUDAUT}

Senior Lecturer in British Studies at Sciences Po Lille (France). His main field of research is the cultural and social history of Britain in the nineteenth and twentieth centuries, especially the history of leisure and sexual politics. Recent articles include "'Roughs On The Turf' and 'Suburban Saturnalia': Anti-social Behaviour on Victorian Racecourses” (Sarah Pickard (ed.), Antisocial Behaviour in Britain, Palgrave Macmillan, 2014, 239-250) and "Quand le personnel devient politique: nouvelles radicalités et nostalgie de l'ordre moral » (Gilles Leydier, dir. Le Royaume-Uni à l'épreuve de la crise, Paris, Ellipses, 2016, 201-219). He has also edited a book on British political posters: Affiches politiques du premier XXe siècle, Paris, Mare et Martin, 2016. Contact: emmanuel.roudaut [at] sciencespo-lille.eu 